\title{
CERPEN SEBAGAI MEDIA PEMBENTUKAN KARAKTER SISWA
}

\author{
Martono \\ Dosen FKIP Universitas Tanjungpura Pontianak \\ Email:martono_fkipuntan@yahoo.co.id
}

\begin{abstract}
Abstrak: Pembelajaran sastra dimaksudkan untuk meningkatkan kemampuan siswa mengapresiasi karya sastra. Kegiatan mengapresiasi cerpen berkaitan erat dengan latihan mempertajam perasaan, penalaran, dan daya khayal, serta kepekaan terhadap masyarakat, budaya, dan lingkungan hidup. Siswa diharapkan mampu menikmati, menghayati, memahami, dan memanfaatkan karya sastra pada umumnya dan cerpen khususnya untuk mengembangkan kepribadian, memperluas wawasan kehidupan, serta meningkatkan pengetahuan dan kemampuan berbahasa. Diharapkan siswa mampu menikmati, menghayati, memahami, dan memanfaatkan cerpen untuk mengembangkan kepribadian, memperluas wawasan kehidupan, serta meningkatkan pengetahuan dan kemampuan berbahasa. Membaca cerpen akan membantu siswa menjadi manusia berbudaya yang responsif terhadap nilai-nilai luhur dalam kehidupan bermasyarakat. Siswa yang berbudaya demikian diharapkan menjadi manusia yang agung namun tetap sederhana, bebas tetapi mengontrol diri, kuat tetapi penuh kelembutan.
\end{abstract}

Kata Kunci: Pembelajaran Cerpen, Media, Karakter, Siswa.

\section{PENDAHULUAN}

Dalam Undang-Undang Nomor 20 Tahun 2003 tentang Sistem Pendidikan Nasional komitmen tentang pendidikan karakter tertuang dalam Pasal 3 yang menyatakan bahwa pendidikan nasional berfungsi mengembangkan kemampuan dan membentuk watak serta peradaban bangsa yang bermartabat dalam rangka mencerdasakan kehidupan bangsa, bertujuan berkembangnya potensi peserta didik agar menjadi manusia yang beriman dan bertakwa kepada Tuhan Yang Maha Esa, berakhlak mulia, sehat, berilmu, cakap, kreatif, mandiri, dan menjadi warga negara yang demikratis, serta bertanggung jawab.

Tujuan pendidikan adalah untuk pembentukan karakter yang terwujud dalam kesatuan esensial subjek dengan perilaku dan sikap hidup yang dimilikinya. Paradigma pembangunan pendidikan di

Indonesia, yaitu menempatkan peserta didik sebagai subjek pendidikan (learnercentret education), serta mengarah kepada pendidikan yang memanusiakan manusia secara holistik, mencakup aspek keimanan dan ketakwaan, iptek, estetika, etika, serta kepribadian. Paradigma ini juga mengedepankan pembentukan karakter dan wawasan kebangsaan peserta didik (nation and charakter building) yang justru sangat penting dalam memelihara persatuan dan kesatuan bangsa pada saat ini.

Pendidikan di Indonesia diharapkan tidak hanya membentuk insan Indonesia yang cerdas, tetapi juga berkepribadian 
atau berkarakter, sehingga akan lahir generasi bangsa yang tumbuh dan berkembang dengan karakter yang bernafaskan nilai-nilai luhur bangsa serta agama. Oleh karena itu, bidang studi yang diberikan di sekolah harus bernilai. Satu diantaranya bidang studi yang diberikan di sekolah adalah bahasa dan sastra Indonesia. Bisakah bidang studi ini digunakan untuk membentu karakter peserta didik? Materi apa dan bagaimana menyajikannya?

Pembelajaran bahasa dan sastra Indonesia di sekolah dapat dipergunakan untuk pembentuk karakter siswa sebagai generasi penerus bangsa kita tercinta. Diharapkan siswa memiliki kemampuan menggunakan bahasa Indonesia untuk meningkatkan kemampuan intelektual (berpikir kreatif dan disiplin, menggunakan akal sehat, menerapkan pengetahuan yang berguna, memahami dan menekuni konsep abstrak, serta memecahkan masalah), kematangan emosional dan sosial.

Berbahasa santun harus sudah menjadi suatu tradisi yang dimiliki setiap individu sejak kecil. Anak perlu dibina dan dididik berbahasa santun sebab anak merupakan generasi penerus yang akan hidup sesuai dengan zamannya. Ingat slogan "gunakanlah bahasa Indonesia yang baik dan benar". Penekanannya adalah penggunaan bahasa secara baik kemudian benar. Indikator baik adalah sopan dan indikator benar adalah kaidah bahasa Indonesia. Dalam makalah ini difokuskan pada pembelajaran sastra.

Pembelajaran sastra dimaksudkan untuk meningkatkan kemampuan siswa mengapresiasi karya sastra. Kegiatan mengapresiasi sastra berkaitan erat dengan latihan mempertajam perasaan, penalaran, dan daya khayal, serta kepekaan terhadap masyarakat, budaya, dan lingkungan hidup. Siswa diharapkan mampu menikmati, menghayati, memahami, dan memanfaatkan karya sastra untuk mengembangkan kepribadian, memperluas wawasan kehidupan, serta meningkatkan pengetahuan dan kemampuan berbahasa.

Pengembangan karakter siswa hanya dapat dilakukan melalui pengembangan karakter individu seseorang. Manusia pada dasarnya hidup dalam lingkungan sosial dan budaya tertentu, maka pengembangan karakter individu seseorang siswa dapat dilakukan dalam lingkungan sosial dan budaya yang bersangkutan. Artinya pengembangan budaya dan karakter bangsa hanya dapat dilakukan dalam suatu proses pendidikan yng tidak melepaskan peserta didik dari lingkungan sosial, budaya masyarakat, dan budaya bangsa. Budaya diartikan sebagai keseluruhan sistem berpikir, nilai, moral, norma, dan keyakinan manusia yang dihasilkan masyarakat.

Sastra pada umumnya dan cerpen khususnya memberikan peluang kepada kita selaku pembaca untuk menjadikannya sebagai sumber moral. Cerpen berpotensi besar sebagai sumber bagi upaya pendidikan karakter karena dalam cerpen membicarakan soal manusia dan kemanusiaan. Betapa pun besarnya peran cerpen untuk membentuk karakter pembacanya, harus tetap dikembalikan kepada kodratnya sebagai karya seni.

\section{PEMBAHASAN}

\section{Pendidikan Karakter}

Pendidikan adalah suatu usaha yang sadar dan sistematis dalam mengembangkan potensi peserta didik. Pendidikan juga merupakan usaha masyarakat dan bangsa dalam mempersiapkan generasi mudanya untuk keberlangsungan kehidupan masyarakat dan bangsa yang lebih baik di masa depan. Keberlangsungan itu ditandai oleh pewarisan budaya dan karakter yang telah dimiliki masyarakat dan bangsa. Oleh 
karena itu, pendidikan adalah proses pewarisan budaya dan karakter bangsa bagi generasi muda dan juga proses pengembangan budaya dan karakter bangsa untuk peningkatan kualitas kehidupan masyarakat dan bangsa di masa mendatang. Sangat erat kaitan antara pendidikan dan karakter, serta budaya.

Ada dua macam paradigma dalam pendidikan karakter. Pertama memandang pendidikan karakter dalam cakupan pemahaman moral yang sifatnya lebih sempit. Kedua melihat pendidikan karakter dari sudut pandang pemahaman isu-isu moral yang lebih luas, terutama melihat keseluruhan peristiwa dalam dunia pendidikan itu sendiri (Martono, 2010:115).

Menurut Singh (2000:175) karakter adalah tabiat atau kebiasaan. Karakter dalam pandangan psikologi adalah sebuah sistem keyakinan dan kebiasaan yang mengarah tindakan seorang individu. Wyne (dalam Sundusiah, 2009) berpendapat karakter berasal dari bahasa Yunani yang berarti "to mark" (menandai) dan memfokuskan pada cara mengaplikasikan nilai kebaikan dalam bentuk tindakan atau tingkah laku. Berdasarkan beberapa pengertian tersebut, karakter adalah watak, tabiat, akhlak, atau kepribadian seseorang yang terbentuk dari hasil internalisasi berbagai kebajikan yang diyakini dan digunakan sebagai landasan cara pandang, sikap hidup, berpikir, dan bertindak.

Pendidikan karakter adalah pendidikan untuk membentuk kepribadian seseorang melalui pendidikan budi pekerti yang hasilnya terlihat dalam tindakan nyata seseorang, yaitu tingkah laku yang baik, jujur, bertanggung jawab, menghormati hak orang lain, kerja keras, dan sebagainya (Lickona, 1991). Hakikat dasar pendidikan karakter adalah apa yang menjadi potensi manusia harus dikembangkan. Ini juga berarti, pada manusia terdapat bibit potensi kebenaran dan kebaikan yang harus didorong melalui pendidikan untuk aktual.

$$
\text { Menurut Koesoema (2007) }
$$

pendidikan karakter merupakan sebuah bantuan sosial agar individu itu dapat menghayati kebebasannya dalam hidup bersama dengan orang lain dalam dunia. Pendidikan karakter bertujuan membentuk setiap pribadi menjadi insan yang berkeutamaan. Pada akhirnya setiap pribadi semakin menyadari dan menghayati individualitasnya, mampu menggapai kebebasan yang dimilikinya tetapi tetap bertanggung jawab moral dengan memperhatikan keberadaan orang lain. Pendidikan karakter bukan hanya berurusan dengan penanaman nilai untuk siswa, melainkan merupakan sebuah usaha bersama untuk menciptakan sebuah lingkungan pendidikan tempat setiap individu dapat menghayati kebebasan yang bermoral.

Tiga komponen penting dalam pendidikan karakter, yaitu pengetahuan tentang moral atau moral knowing, perasaan tentang moral atau moral feeling, dan perbuatan moral atau moral action (Lickona,1992) . Hal ini diperlukan agar peserta didik mampu memahami, merasakan, dan mengerjakan nilai-nilai kebajikan.

Karakter sebagai suatu 'moral excellence' atau akhlak dibangun di atas berbagai kebajikan (virtues) yang pada gilirannya hanya memiliki makna ketika dilandasi atas nilai-nilai yang berlaku dalam budaya (bangsa). Karakter bangsa Indonesia adalah karakter yang dimiliki warga negara bangsa Indonesia berdasarkan tindakan-tindakan yang dinilai sebagai suatu kebajikan berdasarkan nilai yang berlaku di masyarakat dan bangsa Indonesia. Oleh karena itu, Pendidikan Karakter Bangsa diarahkan pada upaya 
mengembangkan nilai-nilai yang mendasari suatu kebajikan sehingga menjadi suatu kepribadian diri warga negara.

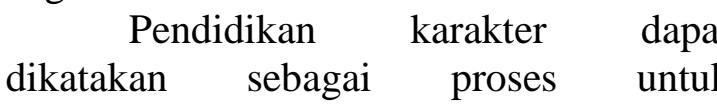
penyempurnaan kepribadian manusia. Ini merupakan usaha manusia untuk menjadikan dirinya sebagai manusia yang berakhlak mulia. Pada dasarnya dalam diri manusia mengalir kebiasaan atau perilaku baik. Proses internalisasi nilai-nilai utama atau nilai-nilai positif yang ada dalam diri manusia.

Pendidikan karakter menanamkan kebiasaan yang baik. Kebiasaan baik dilakukan dan dipraktikkan secara berkesinambungan. Selain itu, aspek perasaan sangat diperlukan dalam pendidikan karakter. Pada dasarnya perbuatan moral merupakan hasil dari dua komponen karakter lainnya. Ada motivasi yang mendorong seseorang berbuat baik. Ada tiga aspek lain dari karakter yang harus dilihat, yaitu: kompetensi, keinginan, dan kebiasaan seseorang.

Pendidikan karakter akan memperluas wawasan para pelajar tentang nilai-nilai moral dan etis yang membuat siswa semakin mampu mengambil keputusan yang secara moral dapat dipertanggungjawabkan. Dalam konteks ini, pendidikan karakter yang diterapkan dalam lembaga pendidikan kita bisa menjadi satu diantara sarana pembudayaan dan pemanusiaan. Diharapkan dapat tercipta sebuah lingkungan hidup yang menghargai hidup manusia, serta menghasilkan pribadi yang memiliki kemampuan intelektual dan moral yang seimbang sehingga masyarakat akan menjadi semakin manusiawi.

Dalam konteks persekolahan, pendidikan karakter mengantar siswa dengan potensi yang dimilikinya menjadi insan-insan yang beriman dan bertakwa, berakhlak mulia, hidup tertip dan disiplin sesuai dengan peraturan yang ada, santun, jujur dan rajin belajar, menghargai sesama manusia, serta peduli terhadap lingkungannya.

\section{Tujuan Pembelajaran Sastra}

Pembelajaran sastra dimaksudkan untuk meningkatkan kemampuan siswa mengapresiasi karya sastra. Kegiatan mengapresiasi sastra berkaitan erat dengan latihan mempertajam perasaan, penalaran, dan daya khayal, serta kepekaan terhadap masyarakat, budaya, dan lingkungan hidup. Siswa diharapkan mampu menikmati, menghayati, memahami, dan memanfaatkan karya sastra untuk mengembangkan kepribadian, memperluas wawasan kehidupan, serta meningkatkan pengetahuan dan kemampuan berbahasa.

Atas dasar pemikiran ini juga dikatakan bahwa kita perlu melaksanakan pendidikan sastra yang humanistis, berorientasi kepada kebenaran, dan bersemangat cinta kepada kehidupan, alam dan Tuhan. Oleh sebab itu, pendidikan sastra memerlukan materi pembelajaran yang sesuai dengan tujuan di atas. Kegiatan penyusunan dan penggalian sastra yang memuat nilai-nilai budaya bangsa perlu dilakukan (Keputusan Kongres Bahasa Indonesia V, 1988:9).

Diharapkan siswa mampu menikmati, menghayati, memahami, dan memanfaatkan karya sastra untuk mengembangkan kepribadian, memperluas wawasan kehidupan, serta meningkatkan pengetahuan dan kemampuan berbahasa. Membaca karya sastra akan membantu siswa menjadi manusia berbudaya yang responsif terhadap nilai-nilai luhur dalam kehidupan bermasyarakat. Siswa yang berbudaya demikian diharapkan menjadi manusia yang agung namun tetap 
sederhana, bebas tetapi mengontrol diri, kuat tetapi penuh kelembutan.

Pembelajaran sastra merupakan bagian dari mata pelajaran yang diberikan di sekolah. Pembelajaran sastra ditujukan untuk meningkatkan kemampuan siswa dalam menikmati, menghayati, dan memahami karya sastra. Menurut Widdowson (1979: 2) bahan pengajaran sastra harus memiliki dua matra. Pertama, bahan pengajaran sastra harus memperhatikan keberadaan teori kesastraan sebagai disiplin yang berkaitan dengan perangkat konsep, jalan pikiran, maupun penemuan sehubungan dengan keberadaan karya sastra. Kedua, bahan pengajaran sastra harus didudukan sebagai subjek yang ditata sesuai dengan disiplin dan prinsip dalam metodologi pendidikan.

Pedidikan karakter melalui cerpen menghindari terbentuknya manusia yang berwajah garang, watak dan perilakunya keras, brutal, dan agresif, selalu memusuhi manusia lain, serta ingin menguasai dan menindas yang lain. Melalui cerpen diharapkan siswa dapat memahami, mengimplementasikan nilai-nilai yang terkandung dalam cerpen yang dibacanya. Pengembangan pendidikan karakter melalui cerpen pada hakikatnya merupakan bagian dari upaya menyiapkan dan membentuk sebuah masyarakat yang berkelangsungannya didasarkan pada prinsip-prinsip moral.

\section{Cerpen yang Diajarkan Kepada Siswa}

Cerpen merupakan satu diantara karya sastra. Sebagai karya sastra, cerpen memiliki nilai yang berguna bagi pembacanya. Nilai-nilai yang terkandung dalam cerpen sebagai wujud dari kehidupan yang terjadi di masyarakat. Permasalahan yang terjadi di kehidupan bermasyarakat dijadikan bahan dalam cerpen. Harus diingat, bahwa karya sastra termasuk cerpen merupakan cermin kehidupan masyarakat.

Pemilihan cerpen yang bermutu dalam pembelajaran di sekolah sangat bermanfaat untuk pendidikan karakter anak karena cerpen pada hakikatnya adalah alat mengajarkan kehidupan. Cerpen yang diberikan sebaiknya yang dapat menggugah sikap dan kepribadian positif siswa. Oleh karena itu, cerpen yang diajarkan kepada siswa bertemakan: (a) religi, (b) persatuan/nasionalisme, (c) kejujuran, (d) kasih sayang, tanggung jawab, (f) disiplin, (g) kerjasama, (h) adil, (i) peduli.

Nilai yang tercermin dalam cerpen dapat dijadikan pembelajaran untuk menumbuhkan sikap positif siswa. Kutipan cerpen berjudul Robohnya Surau Kami karya A.A. Navis di bawah ini dapat menumbuhkan dan meningkatkan karakter religius siswa. Semakin dewasa seseorang harus dapat mengendalikan emosinya. Orang yang tidak dapat menahan marah akan merugikannya. Segala perbuatan baik yang telah lama dilakukan akan sia-sia, bahkan iman dan ibadahnya juga akan berkurang.

"Marah? Ya, kalau aku masih muda, tapi aku sudah tua. Orang tua menahan ragam. Sudah lama aku tak marah-marah lagi. Takut aku kalau imanku rusak karenanya, ibadahku rusak karenanya. Sudah begitu lama aku berbuat baik, beribadat, bertawakal kepada Tuhan. Sudah begitu lama aku menyerahkan diriku kepada_Nya. Dan Tuhan akan mengasihi orang yang sabar dan tawakal (Navis, 1991:9).

Kutipan lain yang terdapat dalam cerpen berjudul Robohnya Surau Kami karya A.A. Navis di bawah ini dapat 
menumbuhkan dan meningkatkan karakter siswa. Pembelajaran yang dapat kita petik adalah manusia harus berusaha untuk memenuhi kebutuhannya. Manusia jangan mementingkan diri sendiri, tetapi harus peduli terhadap lingkungan sehingga kebersamaan dalam bermasyarakat tetap terjaga. Baca kutipan dibawah ini!

"kalau ada, kenapa engkau biarkan dirimu melarat, hingga anak cucumu teraniaya semua. Sedang harta bendamu kaubiarkan orang lain mengambilnya untuk anak cucu mereka. Dan engkau lebih suka berkelahi antara kamu sendiri, saling menipu, saling memeras. Aku beri kau negeri yang kayaraya, tapi kau malas. Kau lebih suka beribadat saja, karena beribadat tidak mengeluarkan peluh, tidak membanting tulang. Sedang aku menyuruh engkau semuanya beramal di samping beribadah. Bagaimana engkau bisa beramal kalau engkau miskin. Engkau kira aku ini suka pujian, mabuk disembah saja, hingga kerjamu lain tidak memuji-muji dan menyembahku saja. Tidak. Kamu semua mesti masuk neraka. Hai, Malaikat, halaulah mereka ini kembali ke neraka. Letakkan di keraknya.

(Navis, 1991:15).

Nilai sopan santun dapat juga ditemukan dalam cerpen. Sikap menghormati orang yang lebih dewasa dapat ditemukan dalam cerpen berjudul Sungai Batu karya Mangunwijaya. Wujud sopan santun yang terdapat dalam cerpen dapat digunakan untuk membentuk karakter positif anak didik, yaitu sikap menghormati orang yang lebih dewasa. Wujud itu tampak saat seseorang akan berjalan dihadapan Romo dengan membongkokkan badannya. Baca kutipan di bawah ini!

Seorang lelaki bertubuh pendek yang membawa linggis beserta seorang muda sangat jangkung yang memikul palu godam besar muncul dari balik batu. Sepejam mata memandangku, lalu spontan mengangkat capingnya sampil membongkok sedikit: "maaf Romo! Perkenankan kami lewat." (Mangunwijaya, 2000:18)

Selain cerpen tersebut, cerpen berjudul Demokrasi karya Putu Wijaya dapat digunakan untuk menanamkan karakter berdemokrasi siswa. Hidup di negara yang menjunjung tinggi demokrasi harus menghargai perbedaan pendapat. Dalam mengambil keputusan lebih mementingkan musyawarah untuk mufakat. Tetapi menjadi masalah apabila orang yang mengatakan dirinya sebagai pendukung demokrasi merusak atau mencemarkan demokrasi dengan menerima imbalan dari seseorang. Baca kutipan cerpen di bawah ini!

Di RT yang saya pimpin itu, seluruh warga pro demokrasi. Mereka mendukung tanpa syarat pelaksanaan demokrasi. Dengan beringas mereka akan berkoar kalau ada yang anti pada demokrasi. Dengan gampang saya bisa mengerahkan mereka untuk maju demi mempertahankan demokrasi. Semua kompak kalau sudah membela demokrasi. Hanya salahnya sedikit, tak seorang pun yang benar-benar mengerti apa arti demokrasi. (Wijaya, 1995:10). 


\section{PENUTUP}

Pembelajaran sastra umumnya dan cerpen khususnya dimaksudkan untuk meningkatkan kemampuan siswa mengapresiasi karya sastra. Kegiatan mengapresiasi sastra berkaitan erat dengan latihan mempertajam perasaan, penalaran, dan daya khayal, serta kepekaan terhadap masyarakat, budaya, dan lingkungan hidup. Siswa diharapkan mampu menikmati, menghayati, memahami, dan memanfaatkan karya sastra untuk mengembangkan kepribadian, memperluas wawasan kehidupan, serta meningkatkan pengetahuan dan kemampuan berbahasa.

Ini sejalan dengan pendidikan karakter untuk membentuk kepribadian atau berakhlak seseorang siswa melalui pendidikan karakter yang hasilnya terlihat dalam tindakan nyata seseorang, yaitu tingkah laku yang baik, beriman, jujur, bertanggung jawab, adil, menghormati hak orang lain, kerja keras. Siswa dengan potensi yang dimilikinya, dapat berlatih berpikir kritis, kreatif, dan inovatif, percaya diri, membangun kemandirian, ikut melestarikan hasil karya budaya bangsa secara sendiri, serta mengembangkan rasa persatuan dan kebangsaan.

\section{DAFTAR BACAAN}

Badan Standar Nasional Pendidikan. 2006. Standar Isi. Jakarta.

Badan Standar Nasional Pendidikan. 2006. Panduan Penyusunan Kurikulum Tingkat Satuan Pendidikan Jenjang Pendidikan Dasar dan Menengah. Jakarta.

Badan Standar Nasional Pendidikan. 2006. Contoh/Model Silabus Mata Pelajaran Bahasa Indonesia. Jakarta.

Daradjat, Zakiah. 2001. Pembinaan Akhlak di Tingkat SMTA dan Perguruan
Tinggi. Dalam Rama Furqona (ed). Pendidikan Agama dan Akhlak Bagi Anak \& Remaja. Ciputat: PT. Logos Wacana Ilmu.

Depdiknas, 2006. Standar Kompetensi dan Kompetensi Dasar Tingkat SMA/MA SMK/MAK Mata Pelajaran Bahasa Indonesia.

Berry, John W; Ype H. Poortinga; Mashall H. Segall; Pierre R. Dasen. Psikologi Lintas-Budaya: Riset dan Aplikasi. Terjemahan Edi Suhardono, 1999. Jakarta: PT Gramedia.

Darma, Budi,1984. 'Moral dalam Sastra' dalam Andy Zoeltom (editor). Budaya Sastra. Jakarta: Rajawali

Depdiknas, 2006. Standar Kompetensi dan Kompetensi Dasar Tingkat SMA/MA SMK/MAK Mata Pelajaran Bahasa Indonesia.

Koesoema, Doni. 2007. Pendidikan Karakter Strategi Mendidik Anak di Zaman Global. Jakarta: PT. Grasindo.

Leech, Geoffrey. 1983. Prinsip-Prinsip Pragmatik. Terjemahan oleh M.D.D. Oka. 1993. Jakarta: UI Press.,

Lickona. T. 1992. Educating for Charakter, How Our School Can Tach Recpect and Responsibility. New York: Bantam Books.

Mangunwijaya, Y.B. 2000. Rumah Bambu. Kumpulan Cerpen. Jakarta: Kepustakaan Populer Gramedia.

Martono, 2010. Pembentukan Karakter Generasi Muda Melalui Pembelajaran Bahasa dan Sastra Indonesia. Dalam Novi Anoegrajekti, Sudartomo Macaryus, dan Endry Boeriswati (Eds.) Idiosinkrasi. Jakarta: UNJ dan Kepel Press.

Navis, Ali Akbar. 1991. Robohnya Surau Kami. Kumpulan Cerpen. Jakarta: Gramedia Pustaka Utama.

Pradopo, R. D. 1990. Pengkajian Puisi. Yogyakarta: Gajah Mada University Pres. 
Singh, Agwan. 2000. Encyclopedia of The Holy Quran. New Delhi: Balaji Offset. Sumardjo, Jakob, \& Saini K.M. 1991. Apresiasi Kesusastraan. Jakarta: Gramedia Pustaka Utama.

Undang-Undang Republik Indonesia Nomor 20 tahun 2003 Tentang Sistem Pendidikan Nasional.

Waluyo, H. J. 1991. Teori dan Apresiasi Puisi. Jakarta: Erlangga.
Wellek, R. dan Warren, A.1977. Teori Kesusastraan.Terjemahan Melani Budiman. Jakarta: PT Gramedia.

Widdowson, H.G. 1979. Stylistic and The Teaching of Literature. London: Longman.

Wijaya, Putu. 1995. Yel. Jakarta: Pustaka Firdaus.

\section{PROFIL}

Nama : Dr. Martono

NIP. $\quad: 196803161994031014$

Pekerjaan : : Dosen FKIP Universitas Tanjungpura Pontianak

(Mengajar di (1) S1 Program Studi Pendidikan Bahasa dan Sastra Indonesia,

(2) S2 Pendidikan Bahasa Indonesia

Tugas Tambahan : Dekan

Alamat : Jln. Urai Bawadi, Gg. Tria 1, no. 1 Pontianak Kalimantan Barat

No. tlp. dan Hp : (0561) 767707, 081522523467, 081345520030

Email : martono fkipuntan@yahoo.co.id 